\title{
Democratic Citizenship and Moral-Religious Values. Axiological Benchmarks in the Education for Democratic Citizenship
} Ion Albulescu 


\title{
Democratic Citizenship and Moral-Religious Values. Axiological Benchmarks in the Education for Democratic Citizenship
}

\author{
Ion Albulescu ${ }^{a^{*}}$ \\ ${ }^{a}$ Faculty of Psychology and Educational Sciences, Babes-Bolyai University, 7 Sindicatelor Street, 400029, Cluj-Napoca, Romania \\ *Corresponding author: ion.albulescu@ubbcluj.ro
}

Abstract

Keywords: democratic citizenship, religion, moral-religious values, education
Democratic citizenship as a concept is not limited to acquiring the legal status of citizen and the right to vote or to be elected in office, which this status grants to individuals. It includes a large range of aspects, from civic conscience, thought and participation, to the political, legal, economic and cultural dimensions of public life in a democratic society. Over the last decades, however, numerous controversies have broken out in the context of strong emerging of the secularization of public life, in terms of tackling the moral and religious dimension of citizenship. In this context, we believe that launching a debate concerning democratic citizenship means looking for appropriate answers to questions such as: What is the relationship between citizenship and religion? How do religious moral values influence the significance of the idea of democratic citizenship? What consequences do they have on education? How are all these aspects operationalised in educational practice? In this study, we are considering the potential answers to such questions.

\section{Zusammenfasung}

\section{Schlüsselworte:}

demokratische

Staatsbürgerschaft, Religion, moralischreligiöse Werte, Bildung.
Demokratische Staatsbürgerschaft als Konzept beschränkt sich nicht nur auf den Erwerb des rechtlichen Status eines Bürgers und des Wahlrechts oder im Amt gewählt werden, die dieser Status Einzelpersonen gewährt. Es umfasst eine breite Palette von Aspekten, von bürgerlichem Gewissen, Gedanken und Partizipation bis hin zu den politischen, rechtlichen, wirtschaftlichen und kulturellen Dimensionen des öffentlichen Lebens in einer demokratischen Gesellschaft. In den letzten Jahrzehnten haben sie jedoch zahlreiche Kontroversen im Zusammenhang mit starker Auftritt der Säkularisierung des öffentlichen Lebens ausgebrochen, in Bezug auf die moralische und religiöse Dimension der Bürgerschaft zu bekämpfen. In diesem Zusammenhang sind wir der Ansicht, dass die Einleitung einer Debatte über die demokratische Staatsbürgerschaft die Suche nach angemessenen Antworten auf folgende Fragen bedeutet: In welcher Beziehung stehen Staatsbürgerschaft und Religion? Wie beeinflussen religiöse moralische Werte die Bedeutung der Idee der demokratischen Staatsbürgerschaft? Welche Folgen haben sie auf die Bildung? Wie werden all diese Aspekte in der pädagogischen Praxis operationalisiert? In dieser Studie betrachten wir die möglichen Antworten auf solche Fragen.

\section{Introduction}

Democratic societies are characterized by affirming and asserting the rights and duties of all citizens, as well as by their responsible involvement in the affairs of their communities. Furthermore, cohesion and social solidarity, legal and moral order are also an intrinsic part of an authentic democracy. Any theoretical approach to democratic citizenship inevitably incorporates an outlook on a series of fundamental values, such as freedom, responsibility, equality of rights, tolerance, justice, equity, diversity and solidarity. Appropriate civic behaviour is based on specific norms and rules established in the spirit of such values.

Citizenship is a legal and political status that allows the individual to participate in public life, but it also represents a role citizen assume as an expression of belonging to a political community. We can say that approaching citizenship from a status perspective is based on a legal interpretation, while the approach of citizenship as a role assumed by an individual, refers to its cultural meaning and civic identity. Nonetheless, democracy and, hence, democratic citizenship is not just a form of political organization, a way in which institutions function or a way of organizing social relations, it is above all, a moral exigency (Burdeau, 1989). Civic behaviour is a social and political construct, but at the same time, it has a significant moral essence. In many circumstances and public life situations, the behaviour of individuals is judged, measured and appreciated from a moral perspective and many citizens use a religious moral reference system in "judging" their peers. This is one of the reasons why the implementation of a well-defined 
operational plan on Education for Democratic Citizenship engages the moral formation of the individual, to the extent that, through its content, the plan also focuses on the regulation of human relations, which are established under appropriate and desirable social values, norms, principles and rules. All these aspects are shaping the moral system of any society; for many citizens, all these regulations are comprised and fostered by a moralreligious system they conform to for most of their lives. Since civic behaviour is not a given, its shaping and subsequent development can be achieved through the Education for Democratic Citizenship. This form of education responds to the societal need to initiate citizens in the culture of democracy, to prepare them to act in accordance with the values and norms that are desirable in any democratic society. At society level, we can identify a series of axiological structures that incorporate universally valid values, norms and attitudes. Once integrated into the personality structure of individuals through education, these structures serve them as indicative guides in everyday life, as evaluation criteria in interpersonal relationships and as standards for their decisions and actions.

Citizenship implies the sharing of values and assumes that people understand, tolerate and possibly support different principles and values. Many scholars in the field of social sciences research consider that there are inherent differences in how people feel and think about public life (Niemi, Junn, 1998). Among the fundamental grounds of any democratic society are the affirmation of pluralism of values, the tolerance of differences and the encouragement of the individual's autonomy. From our perspective, this means that the education for democratic citizenship should explicitly regard morals as an essential element, assumed and valued from different standpoints: morality as a personal option of everyone, given by God, or as a social convention one must accept and practise in order to function as a fully adjusted member of society.

\section{Literature Review}

\subsection{Religion and Citizenship in the Age of secularisation}

The modern debate on citizenship has up until now focused on three major components: the civil element (fundamental human rights), the political element (the right to participate in the wielding of political power, as a member of an organisation exercising political authority, or as a voter of members of such a body) and the social element (the right of individuals to a certain standard of living, as well as their social and economic rights). Beyond these theoretical considerations, the discourse on citizenship evolved and expanded beyond the legal and political domains, placing an increasing accent on the cultural component of citizenship, which is based on the individual's right to establish freely their own axiological consciousness, essential in assuming the status of citizen. Citizenship is more than a legal status or a mere political practice; it is also a way of participating in public life (Stokes, 2008). The attitudes and behaviours individuals are expected to express in civic life must be in line with the values of any democratic society. These values combined to shape a cultural matrix that for most citizens also incorporates religion. The concept of "cultural citizenship" has thus emerged (Rosaldo, 1999; Ong, 1999). Winarnita (2008), for instance, defines cultural citizenship as an expression of involvement in the cultural realm of a given country, even in the absence of legal or official citizenship. In many cases, the approach of citizenship in a democratic society has been and still is dominated by a secularist perspective, which has gone so far as to claim that democracy can only be possible if religion is separated from politics, law and ethics. Moreover, it has been increasingly argued that religion is a private matter, and public space must, therefore, remain secular.

The theory of secularization started to develop since the 1960s, inspired by the works of Max Weber, Die protestantische Ethik und der Geist des Kapitalismus (1904) and Religionssoziologie (1920), in which the prominent German sociologist argued that the values of modern Protestantism and capitalism lead to a "disenchantment" of the world. Max Weber's idea was taken over and further developed by Parsons (1966), Luckmann (1967) and Berger (1969). In The Sacred Canopy (1969), Berger claims that modernity, with its capitalist and individualist ethos dominated by rational values, is, in fact, secular modernity resulting in the decreasing of the force of religion as a hegemonic vision of the world. Consequently, religiosity will be limited to a rather private and reclusive world, manifesting itself almost exclusively as an intimate, innermost virtue (Berger, 1969). 
In this respect, many scholars in the domain argue that secularisation generates pluralism by destroying the transcendental authority of religion as the only source of truth. Thus, religion no longer has dominion, it cannot control or regulate the activities of society and the behaviours of individuals; furthermore, religion no longer inspires the faith of communities and can no longer impose common values (Rémond, 2003). One of the most visible aspects of secularisation is the effect on religious morality; individual consciousness has sovereign power over moral norms and religious identity. The source of religious faith is the individual's consciousness, not a transcendent reality; it is a matter of choice for individuals or for families rather than a means by which the members of a community share a common understanding of the world. The process of modernisation of society must be seen as a process of functional differentiation, emancipation and separation of the secular entities, essentially of the state, economy and science, from the religious sphere (Casanova, 1994). Differentiation is one of the main components of the theory of secularisation that brought on the so-called 'disenchantment' of the world, the separation between state and religion, as well as the development of autonomy of politics, education, scientific, economic and other institutions, from the religious establishment.

Religion offers a form of authoritarian morality originating in the ten divine commandments, while autonomy is the true nature of morality (Hirst, 1974; White, 1993). Following the provisions of such precepts requires religious faith, which ultimately depends on personal choice, but cannot be considered in contemporary secular contexts. In addition, it has been convincingly argued that morality can exist independently of religious faith (White, 1993). In the academic discourse on Western multiculturalism, religious diversity is neglected in favour of cultural and ethnic diversity; hence, most academic works on multiculturalism barely mention religion. Nonetheless, quite a few scholars seem to reject the theory of secularization (Casanova, 1994; Chaves, 1994; Stark, 1999; Stark, Finke, 2000; Parker, Hoon, 2013). The unequivocal distinction between institutional secularisation, the separation occurring between the social system and individual religiosity is a false problem since the secularisation of public space does not invariably lead to the loss of individual religious feelings and commitment (Willaime, 2001). In the modern world, religion has not been dissolved; on the contrary, we are witnessing the dynamics of a heterogeneous world in which religion remains an important, vital social and political force, even in the context of modern pluralism. Many people live their lives according to a religious view of the world, which could lead us to believe that the predictions regarding the secularisation of the world are premature (Parker, Hoon, 2013). Searching for a meaning that transcends the narrow space of empirical existence in this world has been a serious concern of human existence in all societies over the millennia, yet secularisation has largely deprived individuals of their transcendental perspectives over the world and limited the role of institutionalised religion in the public sphere.

Democracy is not the gravedigger of religious expressions, on the contrary: religious tolerance and freedom of religious belief can easily go hand in hand with democracy, given the fact that religions accept the epistemic situation of a world that is the subject of pluralism of visions in all respects. Social space must guarantee the right to diversity (Albulescu, Albulescu, 2017). Thus, the principles of religious freedom and tolerance are closely linked to the development of liberal democracies and are, in fact, at the basis of this type of political construct (Larouche, 2006). They are and should be considered as fundamental rights: "we cannot deny that there is a conceptual link between the universalist foundation of the fundamental right to religious freedom and the normative foundations of any constitutional state, in other words, between democracy and human rights" (Habermas, 2003, pp. 153-154). The democratic idea of religious tolerance is based on respect and on acknowledging the free practice of one's religion in a given community. In a democratic society, religious freedom is a fundamental, intrinsic right of any person who may or may not choose to adhere to certain values. In a democratic society, citizens may choose not to be worshippers (from a religious standpoint), but believers are inherently considered citizens, individuals who are free to express their religious freedom, nonetheless. Citizens can base their actions on religious values in order to pursue the "common good"; this is a model that can be found in most religious traditions and is accessible to believers and non-believers likewise. The pursuit of the "common good" allows members of a community to build bridges and maintain a constructive dialogue with their peers, despite the religious, ethnic, ideological or cultural 
differences between them. Nökel and Stauth (2005) claim that secular public life should be open to religious expressions and manifestations as a need for communication in the context of democratic systems where communities base their values on togetherness, as well as on differences and diversity.

\subsection{The moral dimension of democratic citizenship}

From a common-sense perspective, the term "morals" designates a set of standards in relation to which individuals, groups or entire communities decide to adapt and govern their behaviours, by making a clear distinction between the legitimate or acceptable and the illegitimate and unacceptable, in pursuing their goals. This type of perspective on things leads us to understand morality as a daily practice, as a phenomenon that is experienced directly by individuals; those supporting and favouring it may derive the satisfaction of being appreciated and rewarded, or, on the contrary, may be put to the inconvenience of being denigrated by someone or by public opinion. However, not all uses of the term morality must be associated with a concrete activity. In our opinion, the purely spiritual charge of the term itself is full of meaning. We can talk about the existence of moral norms applicable to specific domains or concrete activities, but there are also moral standards and norms applicable to all people, regardless of the particular situation in which they might find themselves. Morality is an essential dimension of human existence, of social expression, as well as of well-balanced relationships between peers. From an operational perspective at a micro (individual, groups) and macro level (communities and societies), morality can and should be considered as a vital element in the education for democratic citizenship, since "democratic citizenship is the means by which members of a moral community project the norms and values they adopt and abide by, into the public space" (Miroiu, Blebea Nicolae, 2001, p. 73). In a democratic society, the association between morality and citizenship is necessary because the moral dimension is one of the most important ingredients in regulating appropriate human relationships.

The morality of modern man must cope with the pressure of instrumentalization; for many of our peers, morality has become a mere code of conduct, regarded as a system of rules, provisions and duties that establish the behavioural standards inherent in practicing a profession (part of the legal, medical ethics, etc.) or in a certain sphere of activity (business ethics, for instance). Morality is thus reduced to the formal observance of arbitrary rules, beyond which the life of individuals often boils down to a sum of masks and roles with moral function, which they play out in various circumstances of public life. Furthermore, morality is reduced to a conformist attitude and behaviour in relation to the expectations of others and to an appearance of moral involvement with our peers. Under such circumstances, the morality based on Christian precepts understood as an inner experience that generates sense and meaning to the human existence, and as a manifestation of authentic human dimensions suffers. Any social practice involves norms and rules that must be observed. When one devotes themselves to a certain practice, it involves accepting the authority of the norms concerned; moreover, the need to adjust and match one's own performance in accordance with the moral principles they abide by it also involves submitting one's own attitudes, choices, preferences and tastes to the already adopted regulations and standards, which commonly defines practice (MacIntyre, 1998). Rules are obviously not immune to criticism, but we cannot engage in a certain practice without first accepting the authority of the best standards achieved so far in that particular field. Respect for norms, which are intrinsically part of practice, also implies fairness in judging one's own person and actions, as well as those of others. This type of morality works mainly by influencing and sometimes coercing people to display certain attitudes and behaviours. At the same time, even a narrow-minded type of morality is unlikely to function entirely in the language of norms. On the other hand, when we discuss the notions of "citizenship" and "civic behaviour" we can only relate to the notion of "morality" since citizenship involves a moral responsibility towards our peers (Dalton, 2008).

The moral relationship is one of the many forms of regulating human cohabitation. It calls for such behaviour that ensures the promotion of social connections and benefits, along with the private interests that cannot be ignored. Its structuring and regulatory role lie in the fact that it urges individuals to display socially accepted behaviours. Morality integrates a certain system of commandments that indicate what choices are socially appreciated, accepted and even treasured; this is one of the reasons why from the perspective of these 
commandments, various human relationships appear expressed in an ideal form. A behaviour based on moral precepts is only one of the possible behaviour's individuals may exhibit in society, hence the need to evaluate the actions of our peers, which can occur on several levels. The community can judge the one who displays a certain behaviour, but they can also self-assess their actions from a moral standpoint. The act of assessing one's own and other individuals' behaviours is a specific form of manifestation of the moral relationship.

Among the values of civic behaviour that can obviously be observed at the level of different individually and collectively-displayed behaviours, we can mention some of the essential moral values, such as responsibility, solidarity, equality, dignity, respect for others, respect for property etc. Therefore, civic behaviour is viewed as a moral quality worth having and developing, and, over time, civic education itself has often been integrated into moral education, or it has often been considered that morality is the basis of civic culture. Calling on Christian ethics, which is and has been done in various circumstances of social life, is often viewed with mistrust since for many people, the words "morals" and "morality" fall under the sign of relativism of everyday life rules. For some, on the other hand, moral-religious education and the education for democratic citizenship are closely linked, while for others, the education for democratic citizenship must be discussed independently from any subject concerning Christian morality.

Citizens' opinions in a pluralistic society may converge towards a certain moral sense that serves public or private purposes. If this can occur, then it is most probably possible for the education for democratic citizenship to promote a certain perspective on morality, without excluding or undermining other points of view. Some of us might be familiar with the notion of morality and all the aspects it encompasses, which for some may seem obvious, but certainly, individuals have the right and freedom to see differently on the matter. Christian ethics does not present itself as a list of prohibitions or mandatory requirements inaccessible to human reason, but as "a light for action" (Jacob, 2015). Neither rigid nor lax, this type of morality is intended to be entirely realistic since its precepts are not being exclusively used by Christians, but universally acknowledged, beyond any cultural, religious and particularities individuals, groups or communities might have.

Cultural identity spans religious symbols but does not exclude them. The religious factor is not limited to the visible effect of its own symbols on the cultural plan, thus contributing to the construct of social sense, as well as to the integration and participation of each individual in public life. The religious factor has an ethical function and a strong influence on the ethos and behaviour of individuals, given the fact that a deep sense of identity of believers comes from these symbols. In this respect, religion fulfils an important function: it motivates the individual to seek introspection and regard themselves as a moral subject, assimilating the Good as a value to the idea of a good life, which can structure the identity of individuals and serve as a principle of group integration (Tétaz, 2002). In our opinion, religious beliefs help to shape the moral identity of individuals in a particular cultural environment, while internalised religious values can intellectually and emotionally mobilise people and nurture their deep identity.

\subsection{Adopting moral-religious values in the Education for Democratic Citizenship}

One of the essential goals of education for democratic citizenship is to promote the culture of democracy and those individual qualities that would make it possible to exercise effectively one's citizenship. Citizenship is context-related, meaning that it can simultaneously have culturally diverse content, given the different mentalities and identities, in accordance with the political community they pertain to. The sense of belonging is based on shared values, a sense of identity and common historical and cultural heritage. Cultural rights, supported by the need to respect diversity, are viewed as a new form of human rights, alongside the political rights, economic and social rights. From this perspective, we can assume that just as tolerance makes no sense outside preconceived ideas, the knowledge of religious principles itself, which structure people's identity and induce ethical values and norms, becomes a key requirement of citizenship.

In our view, religious ethics and culture add considerably to the education for democratic citizenship and will enable tomorrow's adults to pass the test of critical and responsible openness to religious issues in the 
public space (Larouche, 2006). Education for democratic citizenship involves theoretical and operational approaches with a direct impact on the harmonious construct of the personality of each individual and on their relationships with peers, as well as on the development of personal and collective identities and on the circumstances of social integration and harmonious cohabitation. In this respect, Cairns (2001) argues that we should not reject the religious dimension of our modern secular cultures; on the other hand, it is necessary to contextualize the values that our societies and educational systems support, given the fact that students are also members of a society preserving and cherishing certain traditions, values and religious practices. Since religious beliefs may have a powerful influence on students' thoughts and behaviours, education should seriously take them into account (Greer, 1983).

There is no doubt that people without religious beliefs, the "non-believers", in other words, can be moral. Even the opponents of religious education can offer moral guidance (White, 1993), even more so as it is often considered that linking together religious, moral and civic education no longer satisfies the actual educational needs (Jackson, 2004). Hirst $(1972,1981)$ on the other hand, suggests that education and religion are two separate and autonomous forms of interpreting human experiences; therefore, they are logically different from one another. Hirst claims that religion is compatible with a primitive vision of education, but is, however, incompatible with a contemporary conception of education, where the main goals are rationality and objectivity. In contrast, other prominent scholars argue that there is a close link between religious, moral and civic education (Jackson, 2004; Gearon, 2004), by virtue of national, ethnic, religious and cultural identity. From their perspective, religious education can help improve the understanding of citizenship and democratic education of citizens who decide to actively and responsibly participate in the civil matters of public life. Moral-religious values can play an important role in the achieving of education for democratic citizenship, mainly in understanding various social and cultural aspects. The real challenge here is to ensure that people fostering different religious, ethical and moral values, as well as different social, cultural, and linguistic traditions can live together in harmony (Hargreaves, 1994). In addition, schools must offer the appropriate framework where children should be able to fully understand their religious identity as part of their general identity; moreover, all schools should promote it in order to ensure mutual respect and understanding among their students (Miedema, 2006). Such education should support and encourage peaceful cohabitation based on the respect and acknowledgement of the right to religious freedom (Engebretson, 2009).

Education for democratic citizenship is designed to ensure the development and empowerment of individuals to actively participate in all aspects of public life, from voting to specific interventions that aim at influencing political decision-making, from defending and promoting their own rights to behaving responsibly in society. Education teaches people their responsibilities as citizens (Kymlicka, 2001; Weisbrod, 2002; Weinstock, 2004). This is one of the main reasons why every individual should benefit from this form of education so that they understand that democracy does not appear and develops by itself but depends on the participation and involvement of everyone. Another useful lesson it could teach us is that positive results are achieved in terms of public efficiency and personal prosperity, social justice, individual achievement, morality, etc., only by involving all citizens.

However, the education for democratic citizenship is not limited to one or several disciplines included in the curriculum, to which extracurricular activities are added. It also does not limit itself to a certain field of knowledge or a to a predetermined form of social action; it is not restricted to certain institutional frameworks and does not manifest itself only at a certain point in the life of an individual, but transcends all these aspects, by integrating them in a coherent ensemble (Bîrzea, 2000). Therefore, education for democratic citizenship is achieved through multiple interconnected educational approaches. Likewise, the school environment is very important in cultivating the values of democracy. It has often been argued that, in terms of cultivating the values of democracy, the school ethos can effectively overcome the curriculum and the actually taught courses (Taylor, 1996). On the other hand, Donnelly (2000) suggests that school ethos can be described as a phenomenon that expresses the social reality of a school or because of the social interaction existing within that educational institution. Achieving the goals of the education for democratic citizenship is based on fundamental values according to which attitudes and behavioural norms are structured. 
However, it is necessary to accept the pluralism of moral and religious values, the sensitivity to other cultures and intercultural dialogue, which do not exclude the existence of a common set of values and principles on which civic identity is based. Teachers need to raise their students' awareness of the moral dimension of social and political issues (Kibble, 1998; Pring, 1999), all the more so since there is a sense of lack in this respect (Davies 2000; Kerr 2000). The potential success of the education for democratic citizenship in schools depends largely on the involvement of students in the debate of real-life situations (Campbell, 2005; Pasek, Feldman, Romer \& Jamieson 2008; Torney-Purta, 2002). However, schools offer few opportunities to students in this respect, while they prefer to provide educational content in an academic form (Torney-Purta, 2002).

The individual develops as an autonomous personality through maintaining relationships with others and in line with certain values they hold. Exercising the status as a citizen in a democratic society also involves an ethical component, for many of us, an essential ethnic and religious aspect of living in society. Moral values such as freedom, justice, equality, tolerance and solidarity, require self-respect and respect for our peers, the ability to maintain civil and respectful communication, the ability to reflect and self-reflect on violence in society, and how it can be controlled in order to resolve conflicts, etc. Internalising these values also implies the acceptance of differences and diversity, including those rooted in religion, the fostering of recognition and appreciation, trust in others, etc. Religion guides human behaviour through a series of commandments, passed down as ideal models of conduct. From such a perspective, religious morality provides the foundation for any educational approach. From the perspective of believers, any educational action is permanently linked to this fact; education is the starting point, since it provides the content for growth, and it also serves as a fundamental goal, through the criteria on which the assessment of the level of goal achievement and of school performance is based.

\section{Conclusions}

The behaviour of individuals in society is governed by values and norms, of traditions and customs, all being viewed as factors determining certain types of conduct.
The active participation of the individual in the life of their community is conditioned by the internalisation of these axiological milestones, by the level of development of the social and cultural dimensions of their personality, achieved by major educational influences from the individual's entire social environment. Education for democratic citizenship can be achieved through different manners and formats; it is, in fact, a continuous approach that starts in early childhood and is reinforced especially throughout the school years. In the form under which it is carried out in schools nowadays, education for democratic citizenship ignores the fact that moral-religious values are relevant to the construct of a good citizen's character. For example, in the school curriculum for the discipline Civic Education, 3rd and 4th grades (2014) and in the curriculum for the discipline Social Education Education for Democratic Citizenship, grade 7th (2017), the meaningful references relating to religion, religious identity, and moral-religious values, are missing. Education for democratic citizenship goes beyond the school environment since it is also achieved through contributions from organizations that have a genuine formative potential (the Church, mass media, NGOs, etc.). This type of education involves lifelong learning, in any social condition and in any form of human activity, in order to ensure the acquiring, renewal, completion and improvement of a wide range of knowledge and skills that are key to the success of the individual's participation in public life.

\section{Authors note:}

Ion Albulescu is University habilitated Professor and Ph.D. Coordinator at the Faculty of Psychology and Sciences of Education (Babeş-Bolyai University, ClujNapoca, Romania) Department of Educational Sciences, Faculty of Psychology and Educational Sciences. His research interest is reflected in a series of studies, articles and books published by prestigious international and national editors. The Professor Albulescu teaching and research area covers several educational domains such as Educational Alternatives, Comparative Education, Pedagogical Theories and History of Educational Thinking etc. 


\section{References}

Albulescu, I., Albulescu, M. (2017). The moral-religious dimension of education for the democratic citizenship. In Ion Albulescu, Adriana-Denisa Manea, Iuliu-Marius Morariu (Eds.). Education, Religion, Family in the contemporary society. Saarbrücken: Lambert Academic Publishing, , pp. 1930.

Bîrzea, C. (2000). Educaţia pentru cetăţenie democratică. Perspectiva învăţării permanente. Consiliul Europei, Strasbourg.

Berger, P.L. (1969). The Sacred Canopy: Elements of a Sociological Theory of Religion. New York: Anchor Books, Doubleday \& Co. Inc., Garden City.

Burdeau, G. (1989). Démocratie. In Enciclopedia Universalis (corpus 7). Sous la présidence de P. Baumberger. Paris: E.U. (Ed.).

Cairns, J. (2001). Religious Perspectives on values, culture and education. In J. Cairns, D. Lawton, and R. Gardner (Eds.). Values, Culture and Education: World Yearbook of Education 2001. London: Kogan Page, pp. 46-66.

Campbell, D.E. (2005). Voice in the classroom: how an open classroom environment facilitates adolescents' civic development. In CIRCLE Working Paper Series. Available at: http://

www.civicyouth.org/PopUps/WorkingPapers/WP28campbel 1.pdf (accessed at 20.10.2018).

Casanova, J. (1994). Public Religions in the Modern World. Chicago, IL: The University of Chicago Press.

Chaves, M. (1994). Secularization as Declining Religious Authority. In Social Forces, 72(3), pp. 749-774.

Donnelly, C. (2000). In Pursuit of School Ethos. In British Journal of Educational Studies, 48(2), pp. 134-154.

Engebretson, K. (2009). In Your Shoes: Inter-Faith Education for Australian Schools and Universities. Ballan: Connor Court Publishing.

Gearon, L. (2004). Citizenship through Secondary Religious Education. London and New York: Routledge Falmer.

Gibson, C., Levine, P. (2003). The Civic Mission of Schools. A Report from Carnegie Corporation of New York and CIRCLE: The Center for Information and Research on Civic Learning and Engagement. Available at: http://www.civicmissionofschools.org/

site/campaign/cms_report.html (accessed at 12.08.2019).

Greer, J.E. (1983). Religious and Moral Education: an Exploration of some Relevant Issues. In Journal of Moral Education, 12(3), pp. 92-98.

Habermas, J. (2003). De la tolérance religieuse aux droits culturels. In Cités, 13, Available at: http:/www.cairn.info/revue-cites-2003-1-htm, DOI: 10.3917/cite.013.0151 (accessed at 15.08.2019).

Hargreaves, A. (1994). Changing Teachers, Changing Times: Teachers' Work and Culture in the Post-modern Age. London: Cassell.

Hirst, P. (1972). Christian Education: A Contradiction in Terms? In Learning for Living, 11(4), pp. 6-11.

Hirst, P. (1981).Education, Catechesis and the Church School. In British Journal of Religious Education, 3, pp. 85-93.

Jacob, P. (2015). La morale chrétienne, carcan ou libération? Paris: Desclée De Brouwer.
Jackson, R. (2004), Citizenship as a replacement for religious education or RE as complementary to citizenship education? In Robert Jackson (Ed.). International Perspectives on Citizenship, Education and Religious Diversity. London and New York: Routledge Falmer.

Kibble, D.G. (1998). Moral education: dilemmas for the teacher. In The Curriculum Journal, 9(1), pp. 51-61.

Kymlicka, W. (2001). Politics in the Vernacular: Nationalism, Multiculturalism and Citizenship. Oxford: Oxford University Press.

Larouche, J.-M. (2006). De la religion dans l'espace public. Vers une société postséculière. In Étique publique, 8(1), Available at: http://ethiquepublique.revues.org/1863; DOI: 10.4000/etiquepublique.1863 (accessed at 10.08.2019).

Luckmann, T. (1967). The Invisible Religion. New York: Macmillan.

MacIntyre, A. (trad.) (1998). Tratat de morală. După virtute. Bucureşti: Editura Humanitas.

Miedema, S. (2006), Educating for Religious Citizenship: Religious Education as Identity Formation. In Marian de Souza, Gloria Durka, Kathleen Engebretson, Robert Jackson and Andrew McGrady (Eds.). International Handbook of the Religious, Moral and Spiritual Dimensions in Education, The Netherlands: Springer, pp. 967-976.

Miroiu, M., Blebea Nicolae, G. (2001). Introducere în etica profesională. Bucureşti: Editura TREI.

Nökel, S., Stauth, G. (2005). Introduction. In Asian Journal of Social Science, 33(3), pp. 355-362.

Ong, A. (1999). Cultural Citizenship as Subject Making: Immigrants Negotiate Racial and Cultural Boundaries in the United States. In Rodolfo D. Torres, Louis F. Miron and Jonathan X. Inda (Eds.). Race, Identity and Citizenship: A Reader. Malden and Oxford: Blackwell Publishing, pp. 262293.

Parker, L., Hoon, C.Y. (2013). Secularity, Religion and the Possibilities for Religious Citizenship. In Asian Journal of Social Science, 41(2), pp. 150-174. Available at: http://ink.library.smu.edu.sg/soss_research/1487, http://doi.org/10.1163/15685314-12341296 (accessed at 21.07.2019).

Parsons, T. (1966). Societies: Evolutionary and Comparative Perspectives. Englewood Cliffs, NJ: Prentice-Hall.

Pasek, J., Feldman, L., Romer, D. \& Jamieson, K.H. (2008). Schools as Incubators of Democratic Participation: Building Long-Term Political Efficacy with Civic Education. In Applied Developmental Science, 12(1), pp. 26-37. Available at: https://doi.org/10.1080/10888690801910526 (accessed at 20.07.2019).

Pring, R. (1999). Political Education: relevance of the humanities. In Oxford Review of Education, 25(1\&2), pp. 7187.

Rémond, R. (trad.) (2003). Religie şi societate în Europa. Iaşi: Polirom.

Rosaldo, R. (1999). Cultural Citizenship, Inequality, and Multiculturalism. In Rodolfo D. Torres, Louis F. Miron and Jonathan X. Inda (Eds.). Race, Identity and Citizenship: A Reader, Malden and Oxford: Blackwell Publishing, pp. 253261.

Stark, R. (1999). Secularization, R.I.P. In Sociology of Religion, 60(3), pp. 249-273. 
Stark, R., Finke, R. (2000). Acts of Faith: Explaining the Human Side of Religion. Berkeley, Los Angeles and London: University of California Press.

Stokes, G. (2008). Towards a Conceptual Framework for Citizenship. In Azyumardi Azra and Wayne Hudson (Eds.). Islam Beyond Conflict: Indonesian Islam and Western Political Theory. Aldershot: Ashgate Publishing, pp. 85-92.

Taylor, M.J. (1996). Voicing their Values: Pupils' Moral and Cultural Experience. In J.M. Halstead, M.J. Taylor (Eds.). Values in Education and Education in Values. London: The Falmer Press, pp. 121-142.

Tétaz, J.-M. (2002). Élements pour une théorie postmétaphysique de la religion à partir de Habermas et de Wittgenstein. In P. Gisel, and J.-M. Tétaz (Eds.). Théories de la religion. Genève, Labor et Fides.

Torney-Purta, J. (2002). The school's role in developing civic engagement: A study of adolescents in twenty-eight countries. In Applied Developmental Science, 6(4), pp. 203-
212. Available

at: http://dx.doi.org/10.1207/S1532480XADS0604_7 (accessed at 17.07.2019).

Weinstock, D. (2004). The Problem of Civic Education in Multicultural Societies. In Alain Dieckhoff(Ed.). The Politics of Belonging: Nationalism, Liberalism, and Pluralism. Lanham: Lexington Books, pp. 107-124.

Weisbrod, C. (2002). Emblems of Pluralism: Cultural Differences and the State. Princeton and Oxford: Princeton University Press.

Willaime, J.-P. (2001). Sociologia religiilor. Iaşi: Institutul European.

Winarnita, M.S. (2008). Motherhood as Cultural Citizenship: Indonesian Women in Transnational Families. In The Asia Pacific Journal of Anthropology, 9(4), pp. 304-318.

White, J. (1993). What place for values? In J. White, and P. O' Hear (Eds.). Assessing the National Curriculum. London: Chapman, pp. 9-14. 